\title{
CSMD3 wt Allele
}

National Cancer Institute

\section{Source}

National Cancer Institute. CSMD3 wt Allele. NCI Thesaurus. Code C143043.

Human CSMD3 wild-type allele is located in the vicinity of $8 \mathrm{q} 23.3$ and is approximately $1215 \mathrm{~kb}$ in length. This allele, which encodes CUB and sushi domain-containing protein 3, is involved in dendrite development. 